\title{
A Review: Testing Antioxidant Activity on Kawista Plants (Limonia acidissima L.) in Indonesia
}

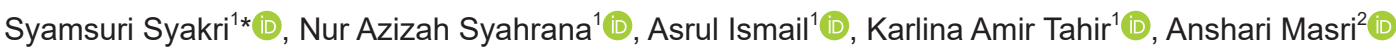 \\ ${ }^{1}$ Department Of Pharmacy, Faculty of Medicine and Health Sciences, UIN Alauddin, Makassar, Indonesia; ${ }^{2}$ Department Of \\ Pharmacy, Faculty of Medicine and Health Sciences, Universitas Muhammadiyah, Makassar, Indonesia
}

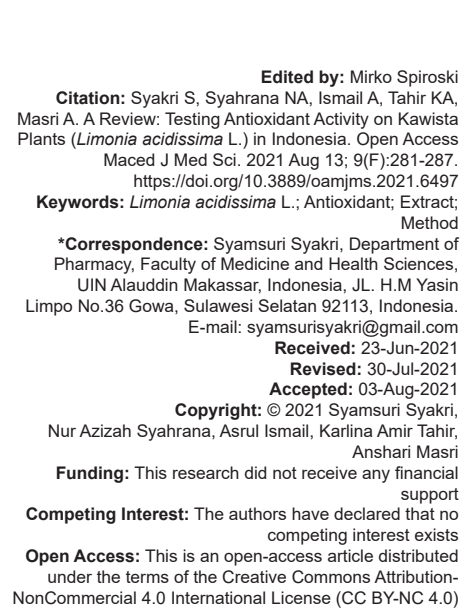

\section{Introduction}

The potential of Indonesian medicinal plants can be seen from their contribution to world drug production. A total of 45 kinds of important drugs produced by the United States were derived from tropical medicinal plants, 14 of which came from Indonesia, such as tapak dara which produces vinblastine compounds which are efficacious as anticancer drugs and pulse porcupines which produce reserpine compounds which are efficacious as antihypertensives. This is a great opportunity for Indonesia to cultivate medicinal plants, as well as their processing industry on a fairly large scale [1].

The use of natural ingredients as medicine is increasing with the issue of back to nature and the economic crisis which has resulted in a decline in people's purchasing power of synthetic drugs which are relatively more expensive. Medicines made from natural ingredients are considered to have almost no or fewer side effects compared to the use of chemicals or synthetics, without reducing the efficacy in treatment. The existence of local wisdom that is owned causes rural communities to have skills in utilizing surrounding plants as medicine [1], [2].

Utilization of plants as traditional medicine is still always used by people in Indonesia because there are several benefits that can be obtained, including low prices, related to the ease of obtaining raw materials, even medicinal plants can be grown alone, the side effects caused by traditional medicines are relatively small so they are safe to be used [3].

In the era of globalization, human life is increasingly facilitated by the presence of technology, but without realizing it, its development is directly proportional to the development of disease. This is because people's lifestyles often have a negative impact on unhealthy living habits such as smoking, consuming instant food, and consuming alcoholic beverages. This can trigger the formation of free radicals in the human body [4].

Free radicals are compounds or molecules that have one or more unpaired electrons that cause these compounds to be very reactive looking for partners by binding electrons to surrounding molecules. Free radicals can come from within the body as part of the results of metabolic processes, while free radicals 
originating from outside the body can be caused by environmental factors, including smoking habits, use of pesticides in food, pollution, radiation, and various physical activities that cause cell damage. Free radicals can trigger various diseases such as obesity, diabetes, hypertension, atherosclerosis, heart, and arthritis [5], [6].

Damage caused by free radicals in the body can basically be overcome by the presence of antioxidants which have the ability to slow down the oxidation process that has a negative impact on the body. Antioxidants will block the oxidation process of free radicals that enter the body so that damage to body cells can be prevented [7].

Based on the description above, it is necessary to conduct a more in-depth study of plants that have antioxidant activity so that they can be used as alternative treatments using natural ingredients without using synthetic drugs that have various side effects.

Kawista (Limonia acidissima L) is a type of plants that belongs to the citrus family (Rutaceae). This plant is still a close relative to the maja fruit, which is a type of citrus originating from tropical and subtropical Asia.

\section{Methods}

\section{Literature search strategy}

The type of research used in this study is library research, namely, research conducted by collecting data from written works in the form of articles that have been published in the form of scientific journals that aim to solve a problem which is basically based on an analysis of the available literature relevant. Judging from its nature, this research is included in descriptive research that focuses on a systematic explanation of facts obtained from research literature sources [6].

In this study, the process of searching for articles online using the Population, Intervention, Comparison, and Outcome method or framework was carried out. The databases used to search for literature are PubMed, Science Direct, Google Scholar, Hindawi, Wiley, and Taylor and Francis which are media for obtaining the desired material in the form of text in various publication formats, from the oldest journal publications to the latest journal publications.

\section{Inclusion and exclusion criteria}

Inclusion criteria are research articles published from 2010 to 2020 in Indonesian and English with sinta and quartile indexes (Q1, Q2, and Q3) with research subjects on antioxidant activity on Kawista plants ( $L$. acidissima L.). For the exclusion criteria, namely, articles are not relevant to the theme of the journal content.

\section{Results}

Based on the literature search strategy, 25 articles were obtained that were in accordance with the research study (Table 1 ).

\section{Discussion}

Overall from the articles that have been analyzed, it is known that the content of chemical compounds that have antioxidant activity found in the Kawista plant ( $L$. acidissima L.) includes phenolic compounds, especially phenolic acids, terpenes, and flavonoids. Methods that can be used to test the antioxidant activity of Kawista ( $L$. acidissima L.) plants include 1,1-diphenyl-2-picrylhydrazyl (DPPH), ferric reducing antioxidant power (FRAP), and 2,2-Azinobis 3-ethylbenzothiazoline 6-sulfonic acid (ABTS). The amount of antioxidant activity is indicated by IC50, which is the concentration of sample solution needed to inhibit $50 \%$ of DPPH free radicals. The smaller the IC50 value, the higher the antioxidant activity. Specifically, a compound is said to be a very strong antioxidant if the value of IC50 is $<50$ ppm (IC50 <50 ppm), strong (50 ppm < IC50 < 100 ppm), moderate (100 ppm < IC50 $<150$ ppm), weak (150 ppm < IC50 < 200 ppm), and very weak (IC50 > 200 ppm) [33].

Based on the article obtained in the study [8] "Antioxidant Potential and Amino Acid Analysis of Underutilized Tropical Fruit L. acidissima L.," compounds that have antioxidant activity found in Kawista fruit ( $L$. acidissima $L$.) are phenolics and flavonoids. The methods used in testing the antioxidant activity are DPPH, FRAP, and ABTS methods. The antioxidant activity obtained in this test was higher in the methanol extract using the DPPH method, which was $0.999 \mathrm{~g} / \mathrm{mL}$, FRAP was $0.708 \mathrm{~g} / \mathrm{mL}$, and the high antioxidant activity in the ethyl acetate extract using the ABTS method was $0.633 \mathrm{~g} /$ $\mathrm{mL}$. The antioxidant activity obtained is classified as very strong because the IC50 value obtained is $<50 \mathrm{ppm}$, this is because in the extraction process, large amounts of extract are obtained and the levels of compounds obtained are also high.

Based on the article obtained in the study [9] "Antioxidant and Radical Scavenging activity of L. acidissima (Linn) Extract," compounds that have antioxidant activity found in Kawista fruit are flavonoids. The method used in testing the antioxidant activity is the $\mathrm{DPPH}$ and ABTS methods. The antioxidant activity of 
Table 1: Results of the study on antioxidant activity of Kawista (L. acidissima L.) plants

\begin{tabular}{|c|c|c|c|}
\hline Article title & Author and year & Journal name & Journal criteria \\
\hline $\begin{array}{l}\text { Antioxidant potential and amino acid analysis of underutilized tropical } \\
\text { fruit } L \text {. acidissima } L \text {. }\end{array}$ & Darsini et al., 2013 [8] & Journal-free radicals and antioxidants & Q1 \\
\hline $\begin{array}{l}\text { Antioxidant and radical scavenging activity of } L \text {. acidissima (Linn.) } \\
\text { extract }\end{array}$ & Mandade and Jadhav, 2013 [9] & Planta Medica & Q1 \\
\hline $\begin{array}{l}\text { Chemical constituents, in vitro antioxidant, and antimicrobial activities } \\
\text { of essential oil from the fruit pulp of wood apple }\end{array}$ & Senthilkumar and Venkatesalu, 2013 [10] & Industrial Crops and Products & Q1 \\
\hline $\begin{array}{l}\text { Optimization of extraction of bioactive compounds from Feronia } \\
\text { limonia (wood apple) fruit using RSM }\end{array}$ & Ilaiyaraja et al., 2015 [11] & Journal Food Chemistry & Q1 \\
\hline $\begin{array}{l}\text { Effect of drying and storage on bioactive components of jambhul and } \\
\text { wood apple }\end{array}$ & Sonawane and Arya, 2014 [12] & Journal of Food Science and Technology & Q1 \\
\hline $\begin{array}{l}\text { Phytochemical investigation and in vitro antioxidant activity of extracts } \\
\text { from leaves of } L \text {. acidissima Linn. (Rutaceae) }\end{array}$ & Attarde et al., 2011 [13] & Journal of Pharmacy Research & Q2 \\
\hline $\begin{array}{l}\text { Antidiabetic and antioxidant activity of } L \text {. acidissima Linn. in alloxan- } \\
\text { induced rats }\end{array}$ & Ilango and Chitra, 2010 [14] & Der Pharmacia Lettre & Q3 \\
\hline $\begin{array}{l}\text { Wound healing and antioxidant activities of the fruit pulp of } \\
\text { L. acidissima Linn. (Rutaceae) in rats }\end{array}$ & Illango and Chitra, 2010 [15] & Journal of Pharmaceutical Research & Q3 \\
\hline $\begin{array}{l}\text { Phytochemical screening, antibacterial and antioxidant activity of } \\
\text { L. acidissima L. }\end{array}$ & Kalkar, 2012 [16] & Bionano Frontier & Q3 \\
\hline Antioxidant and cytotoxic activity of $L$. acidissima $L$. & Shermin et al., 2012 [17] & Journal of Pharmaceutical Chemistry & Q3 \\
\hline $\begin{array}{l}\text { Evaluation of the antioxidant and cytotoxic activities of the stem bark } \\
\text { of } L \text {. acidissima (Family: Rutaceae) }\end{array}$ & Khosru et al., 2013 [18] & $\begin{array}{l}\text { International Journal of Research and Development } \\
\text { in Pharmacy and Life Sciences }\end{array}$ & Q3 \\
\hline $\begin{array}{l}\text { Antioxidant activity of jambhul, wood apple, ambadi, and ambat } \\
\text { chukka: An indigenous lesser known fruits and vegetables of India }\end{array}$ & Sonawane and Arya, 2013 [19] & Journal of Food Science and Technology & Q3 \\
\hline In vitro antioxidant activities of Feronia limonia Linn. & Hanchinalmath and Londonkar, 2014 [20] & $\begin{array}{l}\text { Indo American of Journal of Pharmaceutical } \\
\text { Research }\end{array}$ & Q3 \\
\hline $\begin{array}{l}\text { Cytotoxic and antioxidant properties of fractions isolated from Feronia } \\
\text { elephantum }\end{array}$ & Nattudurai et al., 2014 [21] & $\begin{array}{l}\text { International Journal of Pharmacy and } \\
\text { Pharmaceutical Sciences }\end{array}$ & Q3 \\
\hline $\begin{array}{l}\text { Evaluation of nutritional, phytochemical, antioxidant, and antibacterial } \\
\text { activity of exotic fruit " } L \text {. acidissima" }\end{array}$ & Pandey et al., 2014 [22] & Journal of Pharmacognosy and Phytochemistry & Q3 \\
\hline $\begin{array}{l}\text { Nutritional compositions, antioxidant and antimicrobial activities of } \\
\text { exotic fruit } L \text {. acidissima } L \text {. }\end{array}$ & Naing et al., 2014 [23] & Myanmar Korea Conference Research Journal & Q3 \\
\hline $\begin{array}{l}\text { Phytochemical screening and evaluation of antioxidant potential of } \\
\text { Feronia limonia leaves and fruit extracts }\end{array}$ & Nachimuthu et al., 2014 [24] & Journal of Chemical and Pharmaceutical Sciences & Q3 \\
\hline $\begin{array}{l}\text { Evaluation of bioactive compounds and antioxidant activity of some } \\
\text { wild fruits by in vitro assays }\end{array}$ & Srividya and Chandra, 2015 [25] & $\begin{array}{l}\text { International Journal of Pharmaceutical Sciences } \\
\text { and Research }\end{array}$ & Q3 \\
\hline $\begin{array}{l}\text { In vitro antioxidant activity of Feronia limonia bark relevant to the } \\
\text { treatment of oxidative stress mediated neurodegenerative disorders }\end{array}$ & Akter et al., 2016 [26] & World Scientific Research & Q3 \\
\hline Pharmacological properties of Feronia limonia fruit pulp & Oo et al., 2017 [27] & Indo American Journal of Pharmaceutical Research & Q3 \\
\hline Effect of solvent on antioxidant activities of Feronia limonia fruit & Srivastava et al., 2020 [28] & $\begin{array}{l}\text { International Journal of Pharmaceutical Sciences } \\
\text { and Research }\end{array}$ & Q3 \\
\hline $\begin{array}{l}\text { Aktivitas antioksidan senyawa kumarin Ter-O-Geranilasi dari akar } \\
\text { L. acidissima L. }\end{array}$ & Tjahjandarie et al., 2017 [29] & Journal of Tropical Pharmacy and Chemistry & S2 \\
\hline $\begin{array}{l}\text { Uji Aktivitas Antioksidan dari Ekstrak Buah Kawista (L. acidissima) } \\
\text { Menggunakan Spektrofotometer UV-VIS }\end{array}$ & Rustiah and Umriani, 2018 [30] & Indonesian Journal Chemistry and Research & S3 \\
\hline $\begin{array}{l}\text { Aktivitas Antioksidan dari Ekstrak Metanol Buah Kawista } \\
\text { (L. acidissima) dengan Metode DPPH (1,1-difenil-2-pikrilhidrazil) }\end{array}$ & Kusuma et al., 2020 [31] & Saintech Farma Jurnal Ilmu Kefarmasian & S3 \\
\hline $\begin{array}{l}\text { Aktivitas Antioksidan Ekstrak Daun dan Kulit Buah Kawista } \\
\text { (L. acidissima L.) Asal Kabupaten Karawang }\end{array}$ & Rahmi and Rahmadewi, 2020 [32] & Jurnal MIDPRO & S3 \\
\hline
\end{tabular}

(L. acidissima L.) Asal Kabupaten Karawang

Kawista fruit with the DPPH method, which is $20 \mathrm{~g} / \mathrm{mL}$, is very strong because the value is $<50 \mathrm{ppm}$ and in the ABTS method, $60 \mathrm{~g} / \mathrm{mL}$ is considered strong because the value is $50 \mathrm{ppm}<\mathrm{IC} 50<100 \mathrm{ppm}$. The IC50 results obtained are not the same because the test methods and reagents used are also different.

Based on the article obtained in the study [10] "Chemical Constituents, in vitro Antioxidant and Antimicrobial Activities of Essential Oil from the Fruit Pulp of Wood Apple," compounds that have antioxidant activity found in Kawista fruit essential oil are terpenes. The method used in testing the antioxidant activity is the DPPH and ABTS methods. The antioxidant activity of the DPPH method has an IC50 of $41.35 \mathrm{~g} / \mathrm{mL}$ and the ABTS method is $30.28 \mathrm{~g} / \mathrm{mL}$ which is classified as very strong, with an IC50 value of $<50 \mathrm{ppm}$. This is because in the extraction process, a lot of solvents are used so that the Kawista fruit essential oil produced is also a lot as well as the content of compounds that act as antioxidants.

Based on the article obtained in the study [11] "Optimization of Extraction of Bioactive Compounds from Feronia limonia (Wood Apple) Fruit Using Response Surface Methodology," a compound that has antioxidant activity found in Kawista fruit is phenol. The method used in testing the antioxidant activity is the DPPH and ABTS methods. The antioxidant activity of the DPPH method was $81.60 \%$ (strong) and the ABTS method was $84.2 \%$ (strong). This happens because in the extraction process, less time is used and the solvent used is small causing the extract yield to be obtained a little so that the antioxidant compounds are not completely attracted.

Based on the article obtained in the study [12] "Effect of Drying and Storage on Bioactive Components of Jambhul and Wood Apple," a compound that has antioxidant activity found in Kawista fruit is phenol. The methods used in testing the antioxidant activity are ABTS (10.31\%), DPPH (36.45\%), and FRAP (0.27\%). This is because the concentration of active compounds contained in the extract in inhibiting free radicals is high so that the IC50 value of the extract is classified as very strong.

Based on the article obtained in the study [13] "Phytochemical Investigation and in vitro Antioxidant Activity of Extracts from Leaves of $L$. acidissima Linn. (Rutaceae)," compounds that have antioxidant activity found in Kawista leaves are flavonoids and flavonols. The method used in testing the antioxidant activity 
is $\mathrm{DPPH}$. The antioxidant activity obtained in the test, namely, the DPPH method from PELA, MELA, and CELA had an IC50 of $269 \mathrm{~g} / \mathrm{mL}$ (very weak), $196.67 \mathrm{~g} / \mathrm{mL}$ (weak), and $143.33 \mathrm{~g} / \mathrm{mL}$ (moderate). Weak antioxidant activity can occur because the extraction process uses petroleum ether, methanol, and chloroform solvents which have small dielectric constants so that their ability to extract antioxidant compounds is also small.

Based on the article obtained in the study [14] "Antidiabetic and antioxidant activity of $L$. acidissima Linn in Alloxan Induced Rats," compounds that have antioxidant activity found in Kawista fruit are flavonoids. The methods used in testing the antioxidant activity are DPPH, FRAP, and ABTS methods. The antioxidant activity of Kawista fruit has an IC50 of $50 \mathrm{~g} / \mathrm{mL}$ which is quite strong. This is because in the extraction process, a large amount of extract is obtained and the levels of compounds obtained are also high.

Based on the article obtained in the study [15] "Wound Healing and Antioxidant Activities of the Fruit Pulp of Limonia acidissima Linn. (Rutaceae) in Rats," compounds that have antioxidant activity found in Kawista fruit are flavanones, alkaloids, and triterpenes. The method used in testing the antioxidant activity is the DPPH method. The antioxidant activity of Kawista fruit has an IC50 of $18.8 \mathrm{~g} / \mathrm{mL}$ which is very strong. This is because in the extraction process, a large amount of extract is obtained so that the levels of compounds obtained are also high.

Based on the article obtained in the study [16] "Phytochemical Screening, Antibacterial and Antioxidant Activity of L. acidissima L.," compounds that have antioxidant activity are found in the leaves, stems, fruit skin, and flesh of the Kawista fruit, namely, tannins, steroids, alkaloids, flavonoids, and glycosides. The method used in testing the antioxidant activity is the DPPH method. The antioxidant activity obtained in the test was at a concentration of 200 ppm extract, namely, leaves $(57.34 \mathrm{~g} / \mathrm{mL})$, stems $(55.94 \mathrm{~g} / \mathrm{mL})$, fruit skins $(55.94 \mathrm{~g} / \mathrm{mL})$, and fruit flesh $(40,55 \mathrm{~g} / \mathrm{mL})$; extract concentration of $400 \mathrm{ppm}$, namely, leaves $(67.10 \mathrm{~g} /$ $\mathrm{mL})$, stem $(79.02 \mathrm{~g} / \mathrm{mL})$, fruit skin $(67.83 \mathrm{~g} / \mathrm{mL})$, and fruit flesh $(51.04 \mathrm{~g} / \mathrm{mL})$; extract concentrations of $600 \mathrm{ppm}$ were leaves $(95.80 \mathrm{~g} / \mathrm{mL})$, stems $(82.51 \mathrm{~g} /$ $\mathrm{mL})$, fruit skins $(74.00 \mathrm{~g} / \mathrm{mL})$, and fruit flesh $(76.92 \mathrm{~g} /$ $\mathrm{mL})$; extract concentration of $800 \mathrm{ppm}$, namely, leaves $(96.50 \mathrm{~g} / \mathrm{mL})$, stems $(90.90 \mathrm{~g} / \mathrm{mL})$, fruit skins $(81.81 \mathrm{~g} /$ $\mathrm{mL})$, and fruit flesh $(79.72 \mathrm{~g} / \mathrm{mL})$; extract concentrations of $1000 \mathrm{ppm}$ were leaves $(96.80 \mathrm{~g} / \mathrm{mL})$, stems $(93.00 \mathrm{~g} /$ $\mathrm{mL})$, fruit skins $(88.81 \mathrm{~g} / \mathrm{mL})$, and fruit flesh $(89.67 \mathrm{~g} /$ $\mathrm{mL}$ ). The difference in IC50 values, which is very strong and strong, can be influenced by the concentration of extracts and plant parts used in the antioxidant activity test because the number of compounds produced in each plant part is different.

Based on the article obtained in the study [17] "Antioxidant and Cytotoxic Activity of L. acidissima
L.," compounds that have antioxidant activity found in Kawista bark are phenolic. The method used in testing the antioxidant activity is the DPPH method. The antioxidant activity of Kawista bark was $37.64 \mathrm{~g} / \mathrm{mL}$. The IC50 value in the bark of Kawista is very strong because in the extraction process, the concentration of compounds that inhibit free radicals is high, so the IC50 value obtained is high.

Based on the article obtained in the study [18] "Evaluation of the Antioxidant and Cytotoxic Activities of the Stem Bark of L. acidissima (Family: Rutaceae)," a compound that has antioxidant activity found in the bark of Kawista stems, namely, phenolic. The method used in testing the antioxidant activity is the DPPH method. The antioxidant activity obtained in this test from the ether soluble fraction has an IC50 of $37.64 \mathrm{~g} / \mathrm{mL}$ and the chloroform-soluble fraction has an IC50 of $18.8 \mathrm{~g} / \mathrm{mL}$. The IC50 value obtained was different with the same method due to the difference in polarity of the solvent so that the concentration of compounds acting as antioxidants was also different.

Based on the article obtained in the study [19] "Antioxidant Activity of Jambhul, Wood Apple, Ambadi and Ambat Chukka: An Indigenous Lesser Known Fruits and Vegetables of India," a compound that has antioxidant activity found in Kawista fruit is phenol and flavonoids. The methods used in testing the antioxidant activity are DPPH, FRAP, and ABTS methods. The antioxidant activity of Kawista fruit using the DPPH method was 78.99, the FRAP method was 47.55, and the ABTS method was 20.02. This can be caused by the short extraction time with the maceration method but with the help of an orbital shaker in the stirring process so that the compound that acts as an antioxidant is high.

Based on the article obtained in the study [20] "In vitro Antioxidant Activities of Feronia limonia Linn.," compounds that have antioxidant activity found in Kawista fruit flesh are phenolic. The method used in testing the antioxidant activity is the DPPH, ABTS method. The antioxidant activity obtained in the test in the DPPH method has an IC50 of $1 \mathrm{~g} / \mathrm{mL}$. The ABTS method has an IC50 of $0.95 \mathrm{~g} / \mathrm{mL}$. The antioxidant activity obtained is classified as very strong, namely, $<50 \mathrm{ppm}$. This is because in the extraction process, the extract yields are obtained in large quantities and the levels of compounds obtained are also high.

Based on the article obtained in the study [21] "Cytotoxic and Antioxidant Properties of Fractions Isolated from Feronia elephantum," compounds that have antioxidant activity found in Kawista fruit are phenols and flavonoids. The method used in testing the antioxidant activity is the DPPH method. The antioxidant activity of hexane extract has an IC50 of $71.63 \mathrm{~g} / \mathrm{mL}$. The high IC50 value is due to the fact that in the extraction process, the solvent used is a non-polar solvent so that compounds that act as antioxidants are not completely attracted. 
Based on the article obtained in the study [22] "Evaluation of Nutritional, Phytochemical, Antioxidant and Antibacterial Activity of Exotic Fruit L. acidissima," compounds that have antioxidant activity found in the skin of Kawista fruit are alkaloids, saponins, flavonoids, and phenolics total. The method used in testing the antioxidant activity is the ABTS and FRAP methods. The antioxidant activity of the ABTS method has an IC50 of $0.8 \mathrm{~g} / \mathrm{mL}$ and the FRAP method has an IC50 of $46.03 \mathrm{~g} / \mathrm{mL}$. The IC50 value which is classified as very strong can be caused by a good extraction process using a polar solvent with the help of an orbital shaker so that it can attract compounds that act as antioxidants.

Based on the article obtained in the study [23] "Nutritional Compositions, Antioxidant and Antimicrobial Activities of Exotic Fruit L. acidissima L.," compounds that have antioxidant activity found in Kawista fruit are flavonoids, glycosides, saponins, and tannins. The method used in testing the antioxidant activity is the DPPH method. The antioxidant activity of Kawista fruit has an IC50 of $12.238 \mathrm{~g} / \mathrm{mL}$. The IC50 value which is classified as very strong can be caused by the extract used in the test containing compounds that have high antioxidant activity.

Based on the article obtained in the study [24] "Phytochemical Screening and Evaluation of Antioxidant Potential of Feronia limonia Leaves and Fruit Extracts," compounds that have antioxidant activity found in the leaves, flesh, and skin of the Kawista fruit are tannins and flavonoids. The methods used in testing the antioxidant activity are DPPH, ABTS, and FRAP methods. The highest antioxidant activity was aquadest extract from Kawista leaves, which was $66.12 \mathrm{~g} / \mathrm{mL}$; $89.51 \mathrm{~g} / \mathrm{mL}$; and $94.41 \mathrm{~g} / \mathrm{mL}$ which is quite strong. The high IC50 value can be influenced by the concentration of the extract used in the antioxidant activity test.

Based on the article obtained in the study [25] "Evaluation of Bioactive Compounds and Antioxidant Activity of Some Wild Fruits By in vitro Assays," compounds that have antioxidant activity found in Kawista fruit ( $L$. acidissima L.) are terpenoids, glycosides, steroids, and flavonoids. The method used in testing the antioxidant activity is the DPPH method. The antioxidant activity obtained in the test obtained IC50 of $36.91 \mathrm{~g} / \mathrm{mL}$. This is due to the extraction time with the maceration method where the longer the extraction time is used, the contact time between the sample and the solvent is getting longer so that the number of compounds extracted is increasing.

Based on the article obtained in the study [26] "In vitro Antioxidant Activity of Feronia Limonia Bark Relevant to the Treatment of Oxidative StressMediated Neurodegenerative Disorders," compounds that have antioxidant activity found in Kawista bark are phenolics and flavonoids. The method used in testing the antioxidant activity is the DPPH method. The antioxidant activity of Kawista bark has an IC50 of $15.8 \mathrm{~g} / \mathrm{mL}$. The high antioxidant activity can be caused by the large content of antioxidant compounds so that the electrons donated to free radicals are also many.

Based on the article obtained in the study [27] "Pharmacological Properties of Feronia limonia Fruit Pulp," a compound that has antioxidant activity found in Kawista fruit is phenol. The method used in testing the antioxidant activity is the DPPH and ABTS methods. The antioxidant activity of the DPPH method was 0.98 and the ABTS method was 0.99. The IC50 value which is classified as very strong can be caused by the extract used in the test containing compounds that have high antioxidant activity.

Based on the article obtained in the study [28] "Effect of Solvent on Antioxidant Activities of Feronia limonia Fruit," compounds that have antioxidant activity found in Kawista fruit are phenols and flavonoids. The method used in testing the antioxidant activity is the DPPH and FRAP methods. The antioxidant activity of the DPPH method has an IC50 of $10.63 \mathrm{~g} / \mathrm{mL}$ and the FRAP method is $15.57 \mathrm{~g} / \mathrm{mL}$. The IC50 value which is classified as very strong can be caused by the large amount of solvent and the long maceration time.

Based on the article obtained in the study [29] "Antioxidant Activity of O-Geranylated Coumarin Compounds from L. acidissima L. roots," compounds that have antioxidant activity found in Kawista roots are coumarins (phenolic). The method used in testing the antioxidant activity is the DPPH method. The antioxidant activity of Kawista root from O-geranylated coumarin compounds had IC50 values of $462,13,260,210$, and $234 \mathrm{~g} / \mathrm{mL}$. The IC50 value obtained was different with the same method due to the difference in polarity of the solvent and the ratio of the solvent so that the concentration of compounds acting as antioxidants was also different.

Based on the article obtained in the study [30] "Antioxidant Activity Test of Kawista Fruit Extract ( $L$. acidissima) using a UV-VIS Spectrophotometer," compounds that have antioxidant activity found in Kawista fruit are phenols, especially phenolic acids and flavonoids. The method used in testing the antioxidant activity is the DPPH method. The antioxidant activity of the methanolic extract of Kawista fruit has an IC50 of $127.5 \mathrm{ppm}$ which is categorized as moderate. This is because not all flavonoids are heat resistant. This property depends on the extent to which the flavonoid content in natural ingredients has an $\mathrm{OH}$ group so that each compound in it can hydrogen bond strongly so that breaking the bond requires strong energy.

Based on the article obtained in the study [31] "Antioxidant Activity of the Methanol Extract of Kawista Fruit (L. acidissima) with the DPPH Method (1,1-diphenyl2-picrylhydrazil)," a compound that has antioxidant activity found in Kawista fruit ( $L$. acidissima L.) is flavonoids and tannins. The method used in testing the antioxidant activity is the DPPH method. The antioxidant activity obtained in this test is the methanol extract of 
Kawista fruit peel (L. acidissima L.) obtained IC50 of $233.16 \mathrm{ppm}$ and the methanol extract of Kawista fruit pulp (L. acidissima L.) obtained IC50 of 698.44 ppm which is categorized as having weak antioxidant activity. This can be caused because not all flavonoids are heat resistant. This property depends on the extent to which the flavonoid content in natural ingredients has an $\mathrm{OH}$ group so that each compound in it can hydrogen bond strongly so that breaking the bond requires strong energy.

Based on the article obtained in the study [32] "Antioxidant Activity of Kawista Leaf and Peel Extract $(L$. acidissima L.) from Karawang Regency," compounds that have antioxidant activity found in Kawista leaves are phenolics, flavonoids, triterpenoids, saponins, tannins, and alkaloids while the skin of the Kawista fruit contains phenolics, steroids, saponins, tannins, and alkaloids. The method used in testing the antioxidant activity is the DPPH method. The antioxidant activity obtained in this test is the Kawista leaf sample with aquades solvent, the IC50 value is $945.21 \mathrm{ppm}$, the hot distilled water solvent is the IC50 value is $134.56 \mathrm{ppm}$, the ethanol solvent is $96 \%$, the IC50 value is $296.37 \mathrm{ppm}$, and at Kawista fruit rind sample with aquadest solvent obtained IC50 value of 2.844.67 ppm, hot distilled water solvent obtained IC50 value of 2.187 .65 ppm, 96\% ethanol solvent obtained IC50 value of $381.36 \mathrm{ppm}$. This could be due to the short extraction time using the maceration method $(1 \times 12 \mathrm{~h})$ so that less phenolic compounds were produced.

\section{Conclusion}

1. Compounds in the Kawista plant (Limonia acidissima L.) that has antioxidant activity are phenols, especially phenolic acids, flavonoids, flavonols, triterpenoids, saponins, tannins, terpenes, steroids, alkaloids, and glycosides

2. The methods used for testing antioxidant activity are DPPH (1,1-diphenyl-2-picrylhydrazyl), FRAP (ferric reducing antioxidant power), ABTS (2,2-Azinobis 3-ethyl benzothiazoline 6-sulfonic acid)

3. The antioxidant activity of the Kawista plant (Limonia acidissima L.) has an IC50 with an average value of very strong $(16.45 \mathrm{~g} / \mathrm{mL})$, strong (77.85 g/mL), medium (135.02 $\mathrm{g} / \mathrm{mL})$, weak $(196.67 \mathrm{~g} / \mathrm{mL})$, and very weak $(751.89 \mathrm{~g} / \mathrm{mL})$.

\section{References}

1. Novianti D. Potential and development of medicinal plant species in the village of Meranjat, sub-district of South Indralaya. J IIm Mat IImu pengetahuan. 2017;14(1):1110.
2. Rahimah SB, DjunaediDD, SoerotoAY, BisriT. The phytochemical screening, total phenolic contents and antioxidant activities in vitro of white oyster mushroom (Pleurotus ostreatus) preparations. Open Access Maced J Med Sci. 2019;7(15):2404-12. https://doi.org/10.3889/oamjms.2019.741

PMid:31666837

3. Fadhil M, Desnita E, Elianora D. Test the effectiveness of mahogany seed extract (Swietenia mahagoni (L.) Jacq) as an antipyretic in wistar rats (Rattus norvegicus). B Dent J Kedokt Gigi Univ Baiturrahmah. 2019;4(2):141-9. https://doi. org/10.33854/jbdjbd.106

4. Rahmawati R, Muflihunna A, Sarif LM. Analisis aktivitas antioksidan produk sirup buah mengkudu (Morinda citrifolia L.) dengan metode DPPH. J Fitofarmaka Indones. 2016;2(2):97-101. https://doi.org/10.33096/jffi.v2i2.177

5. Sinaga FA, Harahap U, Silalahi J, Sipahutar H. Antioxidant effect of virgin coconut oil on urea and creatinine levels on maximum physical activity. Open Access Maced J Med Sci. 2019;7(22):3781-5. https://doi.org/10.3889/oamjms.2019.503 PMid:32127975

6. Anwar S. Metodologi Penelitian Bisnis. $6^{\text {th }}$ ed. Jakarta: Salemba Empat; 2016.

7. Miranti M, Wardatun S, Fauzi A. Aktivitas antioksidan minuman jeli sari buah pepaya California (Carica papaya L.). Fitofarmaka. 2016;1:39-52. https://doi.org/10.33751/jf.v6i1.753

8. Darsini DT, Maheshu V, Vishnupriya M, Nishaa S, Sasikumar JM. Antioxidant potential and amino acid analysis of underutilized tropical fruit Limonia acidissima L. Free Radic Antioxid. 2013;3:S62-9. https://doi.org/10.1016/j.fra.2013.08.001

9. Mandade SS, Jadhav JK. Antioxidant and radical scavenging activity of Limonia acidissima (Linn) extract. Planta Med. 2013;73:1-3. https://doi.org/10.1055/s-0033-1351925

10. Senthilkumar A, Venkatesalu V. Chemical constituents, in vitro antioxidant and antimicrobial activities of essential oil from the fruit pulp of wood apple. Ind Crops Prod. 2013;46:66-72. https:// doi.org/10.1016/j.indcrop.2013.01.018

11. Ilaiyaraja N, Likhith KR, Babu GR, Khanum F. Optimisation of extraction of bioactive compounds from Feronia limonia (wood apple) fruit using response surface methodology (RSM). Food Chem. 2015;173:348-54. https://doi.org/10.1016/j. foodchem.2014.10.035

12. Sonawane SK, Arya SS. Effect of drying and storage on bioactive components of jambhul and wood apple. J Food Sci Technol. 2015;52(5):2833-41. https://doi.org/10.1007/ s13197-014-1321-y PMid:25892781

13. Attarde DL, Chaudhari BJ, Bhambar RS. Phytochemical investigation and in vitro antioxidant activity of extracts from leaves of Limonia acidissima linn. (Rutaceae). J Pharm Res. 2011;4(3):766-8.

14. Illango K, Chitra V. Antidiabetic and antioxidant activity of Limonia acidissima linn. in alloxan induced rats. Pharm Lett. 2010;1(1):117-25.

15. llango K, Chitra V. Wound healing and anti-oxidant activities of the fruit pulp of Limonia acidissima linn (Rutaceae) in rats. Trop J Pharm Res. 2010;9(3):223-30. https://doi.org/10.4314/tjpr. v9i3.56281

16. Kalkar SA. Phytochemical screening, antibacterial and antioxidant activity of Limonia acidissima (L). Bionano Front. 2012;5(2):131-3.

17. Shermin S, Aktar F, Ahsan M, Hasan CM. Antioxidant and cytotoxic activitiy of Limonia acidissima L. Dhaka Univ J Pharm Sci. 2012;11(1):75-7. https://doi.org/10.3329/dujps.v11i1.12492

18. Khosru KK, Sultana S, Shermin S, Dey A. Evaluation of the antioxidant and cyto-toxic activities of the stem-bark of Limonia acidissima (Family: Rutaceae). Int J Res Dev Pharm Life Sci. 
2013;2(4):527-30.

19. Sonawane S, Arya SS. Antioxidant activity of jambhul, wood apple, ambadi and ambat chukka: An indigenous lesser known fruits and vegetables of India. Adv J Food Sci Technol. 2013;5(3):270-5. https://doi.org/10.19026/ajfst.5.3256

20. Hanchinalmath JV, Londonkar R. In vitro antioxidant activities of Feronia limonia Linn. Indo Am J Pharm Res. 2014;4(6):1-6.

21. Nattudurai NA, Balachandran C, Paulraj MG, Al Dhabi NA. Cytotoxic and antioxidant properties of fractions isolated from Feronia elephantum. Int J Pharm Pharm Sci. 2014;6(7):210-4.

22. Pandey S, Satpathy G, Gupta RK. Evaluation of nutritional, phytochemical, antioxidant and antibacterial activity of exotic fruit Limonia acidissima. J Pharmacogn Phytochem. 2014;3(32):81-8.

23. Naing $\mathrm{HH}$, Nyoe S, Ko N. Antioxidant and Antimicrobial Activities of Exotic Fruit Limonia acidissima L; 2020.

24. Nachimuthu S, Kumaravel V, Sadhasivam S, Santhosharajan N, Peraman M, Ponnusamy R. Phytochemical screening and evaluation of antioxidant potential of Feronia limonia leaves and fruit extracts. J Chem Pharm Sci. 2014;2:36-40.

25. Srividya N, Chandra M. Evaluation of bioactive compounds and antioxidant activity of some wild fruits by in-vitro assays. Int $\mathrm{J}$ Pharm Sci Res. 2015;6(1):233-8.

26. Akter A, Sadik MG, Kader MA, Islam KM. In vitro antioxidant activity of Feronia limonia bark relevant to the treatment of oxidative stress mediated neurodegenerative disorders.
World Sci. Res. 2016;3(1):62-9. https://doi.org/10.20448/ journal.510/2016.3.1/510.1.62.69

27. Oo WM, Khine MM, Oo WM. Pharmacological properties of Feronia limonia fruit Pulp a review. 2017;7(4):1-7.

28. Srivastava R, Mishra N, Tripathi S, Mishra N. Effect of solvents on antioxidant activities of Feronia limonia Fruit. Int J Pharm Sci Res. 2020;11(7):3385-91.

29. Tjahjandarie TS, Saputri RD, Tandjung M. Antioxidant activity of o-geranylated coumarin compounds from the roots of Limonia acidissima L. J Trop Pharm Chem. 2017;4(2):79-88. https://doi. org/10.25026/jtpc.v4i2.143

30. Rustiah W, Umriani N. Uji aktivitas antioksidan pada ekstrak buah kawista (Limonia acidissima) menggunakan spektrofotometer UV-vis. Indo J Chem Res. 2018;6(1):22-5. https://doi.org/10.30598//ijcr.2018.6-wao

31. Kusuma IM, Veryanti PR, Chairunnisa B. Antioxidant activity of methanol extract of kawista fruit (Limonia acidissima) by DPPH method (1, 1-diphenyl-2-picrylhydrazil). J IImu Kefarmasian. 2020;13(2):60-5. https://doi.org/10.32382/mf.v15i1.820

32. Rahmi H, Rahmadewi R. Aktivitas antioksidan daun dan kulit buah kawista (Limonia acidissima L) asal kabupaten karawang. J MIDPRO. 2020;12(1):118-22. https://doi.org/10.30736/ md.v12i1.149

33. Sarfina J, Handayani D. Uji aktivitas antioksidan dan antibakteri ekstrak daun Ricinus communis L (Jarak Kepyar). J Pedid IImu Kim. 2017;1(1):66-70. https://doi.org/10.33369/atp.v1i1.2725 